Кузик Петро Миколайович аспірант кафедри державного управління Науково-навчального інституту соціальних наук ПрАТ «Вищий навчальний заклад «Міжрегіональна Академія управління персоналом», вул.. Фрометівська, 2, корпус 16, м. Київ, 03039, тел.: (044) 494-47-44, e-mail: iapm@iapm.edu.ua, https://orcid.org/0000-0003-3855-2524

\title{
ПЕРСПЕКТИВНІ МЕТОДИ ОРГАНІЗАЦІЇ БЕЗПЕКИ ВИБОРЧОГО ПРОЦЕСУ: ФОРСАЙТ БЕЗПЕКИ У КОНТЕКСТІ ДЕРЖАВНОГО УПРАВЛІННЯ
}

Анотація. Статтю присвячено новому погляду на застосування методик прогнозування загроз (зокрема - форсайту безпеки) у державному управлінні безпекою виборчого процесу. Наведено коротку ретроспективу становлення форсайту безпеки та особливості його застосування в сучасних умовах.

Форсайт безпеки розглядається як інструмент для прогнозування i формування майбутньої моделі безпеки організації, що дозволяє за короткий період часу отримати доволі точні прогнози про можливі ризики та недоліки в розвитку організації у довготривалій перспективі.

3'ясовано, що форсайт безпеки дозволяє не просто спрогнозувати ймовірні загрози та позитивні наслідки, але й окреслити різні сценарії майбутнього. Визначено, що головною перевагою форсайту, як інструменту безпеки, $є$ можливість усвідомити, що саме варто робити вже зараз, щоб майбутній світ відповідав найбільш оптимістичному прогнозу.

Наголошено на особливому значенні своєчасного проведення прогнозування загроз в ході організації виборчого процесу та оприлюднення частини результатів прогнозування. Оскільки у випадку протидії загрозам, які мають антропогенну природу, оприлюднення прогнозування дає подвійний ефект. 3 одного боку, воно дозволяє розробити план заходів щодо протидії загрозам, а з іншого - позбавляє ентузіазму потенційних зловмисників, які можуть цілком відмовитись від запланованих правопорушень, або ж суттєво їх обмежити, дізнавшись про те, що посадові особи органів державної влади попереджені про можливі події та готові до них.

Серед іншого, автор аналізує особливості застосування форсайту на прикладі карантинних заходів, спрямованих на протидію пандемії COVID-19 й прогнозування тих загроз, які несе за собою як сама епідемія, так і заходи протидії 
їй.

В якості необхідних умов для ефективного застосування форсайту безпеки в ході виборчого процесу, визначено активізацію діяльності науковців і практиків, раціональний добір фахівців, здатних виступити експертами 3 тих чи інших питань, усвідомлення керівництвом держави важливості прогнозування загроз із застосуванням цього методу.

Ключові слова: форсайт; форсайт безпеки; державне управління; прогнозування загроз; майбутнє; експертна діяльність; COVID-19; виборчий процес.

Kuzyk Petro Mykolaiovych Postgraduate student of the Department of Public Administration of the Research and Training Institute of Social Sciences of PJSC "Higher Educational Institution" Interregional Academy of Personnel Management ", 2 Frometivska St., build. 16, Kyiv, 03039, tel.: (044) 494-47-44, e-mail: iapm@iapm.edu.ua, https://orcid.org/0000-0003-3855-2524

\section{THE PROMISING METHODS OF ORGANIZING THE SECURITY OF THE ELECTION PROCESS: SECURITY FORESIGHT IN THE CONTEXT OF PUBLIC ADMINISTRATION}

Abstract. The article is devoted to a new look at the application of threat forecasting techniques (in particular - security foresight) in the state security management of the election process. A brief retrospective of the formation of the security foresight and the peculiarities of its application in modern conditions are given.

Security foresight is seen as a tool for forecasting and shaping the future security model of the organization, which allows for a short period of time to obtain fairly accurate forecasts of possible risks and shortcomings in the development of the organization in the long run.

It has been found that security foresight allows not only to predict probable threats and positive consequences, but also to outline different scenarios for the future. It is determined that the main advantage of foresight as a security tool is the ability to realize what exactly should be done now to make the future world meet the most optimistic forecast.

Emphasis is placed on the special importance of timely forecasting of threats during the organization of the election process and publication of part of the forecasting results. Because in the case of counteracting threats that are anthropogenic in nature, the publication of forecasts has a double effect. On the one hand, it allows to develop a plan of measures to counter threats, and on the other hand, it discourages the enthusiasm of potential criminals, who may completely abandon the planned offenses, or significantly 
limit them by learning that government officials are warned of possible events and ready for them.

Among other things, the author analyzes the peculiarities of the use of foresight on the example of quarantine measures aimed at counteracting the COVID-19 pandemic and predicting the threats posed by both the epidemic itself and measures to combat it.

As necessary conditions for the effective use of security foresight during the election process, it was identifieds the intensification of scientists and practitioners, the rational selection of specialists capable of acting as experts on certain issues, the state leadership's awareness of the importance of forecasting threats using this method.

Keywords: foresight; safety foresight; governance; threat forecasting; future; expert activity; COVID-19; election process.

Постановка проблеми. Ключовими особливостями сучасної безпекової сфери можна вважати не лише надзвичайно широку палітру вже існуючих загроз, але й високу динаміку їх трансформації, або й взагалі - появи нових. При цьому, значу кількість майбутніх загроз можна спрогнозувати якщо не повністю, то бодай частково, і якщо навіть не звести ймовірні збитки до нуля, то щонайменше локалізувати їх, спланувати заходи протидії та ліквідації їх наслідків.

У випадку з безпекою виборчого процесу, дедалі більше зростає роль дистанційної роботи, зокрема - діяльності щодо забезпечення кібербезпеки, відеоспостереження, проведення роз'яснювальної (у тому числі - просвітницької) роботи як з виборцями, так і з учасниками виборчого процесу. Водночас, такі тенденції не усувають і проблеми фізичної безпеки виборчих дільниць, приміщень, де працюють суб'єкти виборчого процесу.

Доволі гостро ці потреби актуалізувалися в 2020 році, зокрема - 3 огляду на впровадження заходів щодо протидії поширенню COVID-19. При цьому, організатори виборчого процесу мають змогу взяти на озброєння численні прогнози загроз, які більшою чи меншою мірою здатні знизити несподіванку від настання того чи іншого малоймовірного процесу.

3 огляду на такий стан справ, особливої актуальності набуває потреба дослідження сучасного інструментарію прогнозування, на кшталт «форсайту безпеки» у контексті реалізації безпеки виборчого процесу.

Аналіз останніх досліджень і публікацій. Проблематика форсайту є доволі опрацьованою у західному науковому просторі. Зокрема, значної уваги вона набула у працях таких західних дослідників як A. Clayton, G. Muller, R. Phaal, N. Taleb. На пострадянському ж просторі форсайт, як явище та інструмент прогнозування, у тому числі в галузях безпекознавства, права та державного управління, досліджували І. Баришев, Р. Кравець, I. Кірнос, С. Кукушкіна, С. Лисенко, С. Серьогіна, Водночас, проблематика форсайту безпеки лишається 
малодослідженою та потребує уваги науковців, які представляють різні галузі знань.

Метою статті $€$ висвітлення нового погляду на застосування методик прогнозування загроз (зокрема - форсайту безпеки) у державному управлінні безпекою виборчого процесу.

Виклад основного матеріалу. 2020 рік, без перебільшення, можна вважати роком відчутного підтвердження необхідності довготривалого планування потенційних ризиків у державному управлінні в цілому та у державному управлінні такими демократичними інститутами, як інститут виборів - зокрема.

Останнім із викликів для науки та практики безпеки виборчого процесу стали місцеві вибори, які проводилися в Україні 25 жовтня 2020 року. В ході підготовки до проведення виборів, серед іншого, окрему увагу було присвячено проблематиці протидії поширенню COVID-19.

При цьому, державні органи, до кола повноважень яких належить забезпечення безпеки в ході проведення виборів, змушені були прогнозувати ризики та потенційні загрози, які можуть мати місце як у день виборів, так i напередодні, або у процесі підрахунку голосів виборців. Так, зокрема, аналітик Комітету виборців України Денис Рибачок, зазначав, що $є$ ризик появи маніпуляцій «через коронавірус». За його словами, «фейками про спалахи хвороби на дільницях можуть залякувати людей i ті просто побояться йти голосувати. Як результат, це може вплинути на, і без того невисоку, явку виборців на місцевих виборах» [1].

Таким чином, задовго до проведення дня голосування, оприлюднювалися обережні прогнози загроз, які можуть мати місце в день виборів. Характерно, що у випадку протидії загрозам, які мають (бодай - частково) антропогенну природу, оприлюднення прогнозування дає подвійний ефект. 3 одного боку, воно дозволяє розробити план заходів щодо протидії загрозам, а з іншого - позбавляє ентузіазму потенційних зловмисників, які дізнавшись про те, що органи державної влади у особі відповідних державних службовців, попереджені про можливі події та готові до них, можуть цілком відмовитись від запланованих правопорушень, або ж суттєво їх обмежити.

В контексті цього варто зазначити, що ні Комітет виборців, ні Центральна виборча комісія дійсно не тішили себе ілюзіями щодо випадкової природи загроз. «Держава має переконати громадян, що для них безпечно голосувати. Інше питання - місцеві політики, які можуть використовувати ігри 3 явкою на свою користь. Коли просто може свідомо поширюватися маніпулятивна неправдива інформація, щоб певні групи виборців не прийшли голосувати. С загальне розуміння, які групи за кого голосують, тож на місцях порахувати це доволі нескладно. Свідомо можуть поширювати фейки, що, наприклад, в цій школі чи 
лікарні спалах коронавірусу, і туди не можна йти голосувати. I це насправді також дуже велика проблема», - зазначав Денис Рибачок [1].

В ході проведення круглого столу, який 2 жовтня організував Український кризовий медіа-центр у рамках програми USAID DOBRE, було також конкретизовано заходи, спрямовані на протидію інформаційним маніпуляціям громадянам було рекомендовано довіряти лише достовірним i перевіреним джерелам. Зокрема, інформації на сайті Міністерства охорони здоров'я, спікерам Центру громадського здоров’я, місцевим лікарям, управлінням охорони здоров'я. Такий перелік назвав заступник міністра охорони здоров'я Віктор Ляшко [1]. Подібне реагування на загрози безпеці проведення виборів свідчить про те, що в нашій державі вже застосовуються окремі складові прогнозування ризиків та планування заходів протидії їм. Однак, наразі відсутній системний підхід до зазначених процесів, а сучасна наука державного управління потребує розробки інструментарію прогнозування загроз безпеці як у короткочасній, так i y довгостроковій перспективі.

У чинному виборчому законодавстві проблематика безпеки розглядається, переважно, фрагментарно. Найчастіше мова йде або про охорону приміщень, де проводяться вибори та підрахунок голосів, або ж про поверхневий аналіз політичних програм на предмет наявності в них загроз державній безпеці України.

Так, зокрема, згідно абзацу другого частини десятої статті 36 Виборчого кодексу України, «працівники правоохоронних органів можуть здійснювати охорону правопорядку в день голосування та при підрахунку голосів лише поза межами приміщення для голосування. У разі виникнення фактів порушення правопорядку голова, заступник голови чи секретар комісії може викликати працівників правоохоронних органів виключно для вчинення дій 3 відновлення правопорядку на період, необхідний для таких дій» [2]. А відповідно до третього абзацу тієї ж частини 36 статті, «в приміщеннях виборчої комісії, в яких встановлено елементи автоматизованої інформаційно-аналітичної системи, мають право знаходитися особи, визначені рішенням Центральної виборчої комісії або відповідної комісії, які забезпечують кіберзахист, кібербезпеку системи та каналів зв’язку, задіяних для забезпечення іiі функціонування, та $є$ співробітниками органів, перелік яких визначено відповідним рішенням Центральної виборчої комісії» [2]. При цьому, останній абзац до частини 10 статті 36 було додано лише влітку 2020 року, згідно із Законом № 805-IX від 16.07.2020 [3]. Таким чином, можна констатувати процес оновлення законодавства у контексті протидії певним видам загроз (у даному випадку - кіберзагрозам), перелік яких буде невпинно поповнюватися.

Стосовно ж аналізу політичних програм, Виборчий Кодекс зазначає, що 
встановлення Центральною виборчою комісією «наявності у передвиборній програмі кандидата положень, спрямованих на ліквідацію незалежності України, зміну конституційного ладу насильницьким шляхом, порушення суверенітету i територіальної цілісності держави, підрив іiі безпеки, незаконне захоплення державної влади, пропаганду війни, насильства, розпалювання міжетнічної, расової, релігійної ворожнечі, посягання на права і свободи людини, здоров’я населення» $є$ підставою для відмови реєстрації кандидатів на пост Президента України (Ст. 104), народних депутатів України у складі партії (ч. 1 п. 3 Ст. 159), депутатів, кандидатів на посаду сільського, селищного, міського голови (ч. 1 п. 3Ст. 230) [3]. I якщо з виявленням положень стосовно «ліквідації незалежності України, зміни конституційного ладу насильницьким шляхом, порушення суверенітету і територіальної цілісності держави, підриву іiі безпеки, незаконного захоплення державної влади» ситуація більш-менш зрозуміла, то питання, якою мірою Центральна виборча комісія фізично здатна визначати спрямованість тих чи інших положень передвиборних програм (з огляду на складність визначення їх наслідків) щодо «розпалювання міжетнічної, расової, релігійної ворожнечі, посягання на права і свободи людини, здоров'я населення», лишається доволі дискусійним, і ще очікує ретельного наукового дослідження.

Тому, окремої уваги заслуговує інструментарій сучасної теорії безпеки, у контексті застосування його наукою державного управління. Значна частина ситуацій, та процесів, які їх включають, є складною і важкопрогнозованою, особливо - у випадку відсутності належної фахової підготовки аналітиків. Так, наприклад, для визначення як потенційно позитивних, так і негативних сценаріїв розвитку в організаціях, спеціалісти дедалі частіше вдаються методу «форсайту безпеки».

Форсайт (англ. Foresight - «передбачення») -являє собою технологію і формат комунікації, які дозволяють учасникам домовитися 3 приводу образів майбутнього, а також, визначивши бажаний образ, узгодити дії в його контексті $[4,5]$. Цікаво, що як i чимало інших сучасних наукових дефініцій, термін «foresight» вперше запропонував письменник-фантаст. У випадку із зазначеним терміном це був Герберт Уеллс. Ще у 1930p. Виступаючи на ВВС, він запропонував впровадити особливу спеціальність - «професор передбачення», який, подібно до історика, буде аналізувати і знаходити застосування майбутнім технологічним відкриттям [5]. В даному випадку мало місце чергове «самовтілюване пророцтво», і Герберт Уеллс став автором чергової наукової дефініції.

Проте, якщо розглядати форсайт саме безпеки як глобальний дослідницький проект закордонних фахівців з безпеки, то ця методика сягає 50-тих років XX століття. Адже вперше офіційно такий метод було впроваджено в США 
корпорацією RAND, яка являла собою стратегічний дослідницький центр, що працює на замовлення уряду і збройних сил США. В подальшому технологія набула поширення у Південній Кореї, Японії та ряді країн НАТО. Спочатку це була важка і досить дорога технологія прогнозування у сфері безпеки, в рамках якої протягом місяців працювало величезна кількість експертів [6]. Однак, за понад 60 років багато чого змінилося, i тепер $є$ багаторізних модифікацій форсайту безпеки. Адже у кожній сфері людської діяльності, і навіть у кожній окремій організації, існує свій спектр прогнозування і життєвий цикл. I якщо в індустрії моди він доволі короткий, і будувати перспективну реконструкцію (тобто - форсайт безпеки) далеко вперед просто не має сенсу, то у геологічній промисловій розвідці, атомній енергетиці, космічних програмах, фахівцям потрібно оперувати стратегічними термінами, щонайменше у 10-20 років (а подекуди - й більше).

Важливу роль у процесі застосування форсайту безпеки грає оцінка загроз, які можуть характеризуватися низькою ймовірністю виникнення, але при цьому мати великий потенціал негативного впливу на майбутнє досліджуваної організації. Загальносвітова пандемія COVID-19 - яскравий приклад подібної події. Такі загрози називають «чорними лебедями», за визначенням одного 3 найвідоміших філософів сучасності Нассіма Талеба [7]. «Чорні лебеді» являють собою точки біфуркації, настільки приховані від поверхневого аналізу, що виявити їх вдається лише на обговореннях на кшталт «форсайт-сесій з безпеки», ілише за умови залучення до цієї проблеми достатньої уяви. Адже про те, що людям дедалі частіше загрожуватимуть не світові війни, а саме епідемії, свого часу попереджали чимало футурологів. I хоча звісно ж, вони не говорили саме про 2020 рік і саме про «COVID-19», ці автори неодноразово підкреслювали, що ми вступаємо в такий світ, в якому інфекції можуть стати більш небезпечною загрозою, ніж будь-коли раніше. Комунікації й сучасний транспорт надзвичайно прискорили подорожі. Якщо навколосвітня подорож Фернандо Магеллана на початку XVI століття тривала майже три роки, а за підрахунками Жюля Верна в кінці XIX століття планету можна було обігнути за 80 діб, то сьогодні, користуючись пасажирським авіаційним транспортом, можна здійснити цю подорож за менш ніж 80 годин. До того ж, з огляду на зростання населення планети i вкрай високий рівень урбанізації, має місце безпрецедентна концентрація людей.

Дослідникам і практикам важливо враховувати, що такі події, які можна віднести до категорії «чорних лебедів», вкрай рідко відбуваються всупереч наявним глобальним загрозам або ж кардинально змінюють їх. В більшості випадків вони їх просто значно посилюють. Така ситуація склалася 3 аутсорсингом, фрілансом, онлайн-навчанням у 2020 році. Адже поява цих сфер 
діяльності й супутніх їм загроз ніяк не пов’язана з пандемією COVID-19. Однак, саме завдяки пандемії ці сфери діяльності дуже швидко зросли, а супутні їм загрози раптово посилилися.

Отож, в цілому форсайт безпеки пов'язаний не стільки з прогнозуванням, яке $\epsilon$ доволі розмитим, скільки 3 проектуванням певної моделі безпеки організації. Адже у основі цього методу лежить розуміння того, що майбутня безпека варіативна і безпосередньо залежить від впроваджених заходів. Тому, цілком погоджуючись із позицією вітчизняного дослідника у галузі інформаційного права та безпекознавства С. О. Лисенка, вважаю, що головним завданням, яке варто вирішити суб'єктам безпеки, є встановлення певного алгоритму заходів, які спільними зусиллями слід зробити вже зараз для того, щоб прийти до бажаного результату в майбутньому [8].

Також, ведучи мову про форсайт безпеки, варто враховувати, що як дослідники, так і практики під цим поняттям часто мають на увазі дещо різні явища. Найчастіше під цими словами мають на увазі саме форсайт-сесії фахівців 3 безпеки. Зазвичай у таких заходах беруть участь експерти, модератор, який веде процес і секретар, який стежить за ходом дискусії і веде всі записи. Оптимальне число учасників - від 7 до 15 осіб, а час на обговорення зазвичай не перевищує кількох днів [9]. В рамках цього процесу спочатку проводяться попередні дослідження і моніторинги, на основі яких будуються гіпотези, і тільки після цього організовуються обговорення групами експертів з безпеки. Такі фахівці починають вибудовувати на основі попередніх висновків та фактів шлях до майбутньої моделі безпеки, прогнозувати, проектувати дорожні карти i домовлятися. При цьому однієї форсайт-сесії 3 безпеки може виявитися недостатньо, і в такому разі планується ряд додаткових. Такі дослідження можуть тривати досить довго і включати в себе участь дуже великого числа фахівців, навіть - 3 кількох країн [10]. А отже, важливу роль у форсайті безпеки відіграє підбір експертів, що ставить нові виклики як перед наукою державного управління, так і перед практикою безпеки виборчого процесу.

Важливо пам'ятати, що створений форсайтом безпеки перспективний план не може вважатися статичним набором фактів, його необхідно регулярно корегувати для відповідності динаміки ситуації. Не варто намагатися ретельно і в точності вгадувати всі загрози $[9,10]$. Адже з одного боку, такий підхід звужуватиме поле прогнозування, і може призвести до ігнорування малоймовірних факторів (вже згадуваних «чорних лебедів»), а з іншого, він може заважати помітити потенційні загрози там, де їх раніше не вбачали. При цьому, як доволі слушно, на нашу думку, зазначає С. О. Лисенко, «в межах адміністративно-правових засад, під час форсайту безпеки не може і не повинно ставитися завдання точно передбачити всі можливі загрози або точно їх описати. Такий абсолютистський підхід $\epsilon$ 
тупиковим. Цілком зрозуміло, що більшість загроз так чи інакше дійсно можуть виникнути. Звичайно, адміністративно-правові засади повинні бути максимально гнучкими, тому що загрози можуть виникати трохи не в тому вигляді, в якому були б описані під час форсайту безпеки» [8, с.82]. Тобто, варто зосереджуватися на прогнозуванні саме загальних обрисів загроз, і якнайширшої їх палітри. Такий підхід дозволить виявити наявні загрози, і в перспективі - прогнозувати «чорні лебеді», які, незважаючи на малу ймовірність здійснення, можуть мати колосальний руйнівний потенціал.

Висновки. Виборчий процес, як частина механізму демократичного державотворення, характеризується не лише високим ступенем невизначеності результату, але й широкою палітрою загроз його безпеці. При цьому, якщо значна частина загроз є загальновідомою (як то - порушення виборчого законодавства учасниками процесу, порушення правопорядку на виборчих дільницях, тероризм, техногенні або природні стихійні лиха, які можуть загрожувати безпечному проведенню виборів), то інші - доволі складно спрогнозувати. Проте, складність прогнозування не означає, що таке прогнозування є неможливим.

У випадку протидії загрозам, які мають (бодай - частково) антропогенну природу, оприлюднення прогнозування дає подвійний ефект. 3 одного боку, воно дозволяє розробити план заходів щодо протидії загрозам, а з іншого - позбавляє ентузіазму потенційних зловмисників, які дізнавшись про те, що органи державної влади (у особі відповідних державних службовців) попереджені про можливі події та готові до них, можуть цілком відмовитись від запланованих правопорушень, або ж суттєво їх обмежити. Особливо актуалізується такий підхід у сфері виборчого процесу, оскільки час, місце, дата проведення виборів заздалегідь відомі, а самі вибори відбуваються регулярно і циклічно, через доволі значні (кількарічні) проміжки часу. Тобто у випадку оприлюднення прогнозування антропогенних загроз напередодні проведення виборів, потенційні зловмисники не лише змушені будуть відмовитися від запланованих заходів, але й не матимуть достатньо часу для розробки нових. Відповідно, їм доведеться або повністю відмовитись від втручання у виборчий процес (що, 3 огляду на зазначену нами періодичність виборів, усуває загрозу на роки), або ж - діяти терміново, за менш продуманим планом (або взагалі - експромтом), що підвищує ймовірність виявлення, локалізації та зупинення їх дій правоохоронними органами.

Доволі ефективно проявляє себе такий метод прогнозування як «форсайт безпеки», який дозволяє не лише будувати загальні прогнози щодо загроз, але й виявляти потенційні загрози, невраховувані раніше. Однак, результативне застосування форсайту безпеки, потребує не лише активної діяльності науковців $i$ практиків, але й раціонального добору фахівців, здатних виступити експертами 3 
тих чи інших питань, а головне - розуміння важливості застосування форсайту безпеки 3 боку керівництва держави в цілому й керівництва тих чи інших державних установ - зокрема.

\section{Jimepamypa:}

1. Місцеві вибори 2020 i COVID: що варто знати про правила безпеки. Портал «Децентралізація». 07.10.2020. URL: https://decentralization.gov.ua/news/12858?page=3

2. Виборчий Кодекс України: Закон України від 19 грудня 2019 № 396-IX URL: https://zakon.rada.gov.ua/laws/show/396-20\#Text

3. Про внесення змін до деяких законодавчих актів України щодо вдосконалення виборчого законодавства: Закон Українивід 16 липня 2020 № 805-IX URL: https://zakon.rada.gov.ua/laws/show/805-20\#Text

4. RoadmapReportConcerningtheUseofNanomaterialsintheAutomotiveSector (2006) // NanomaterialRoadmap 2015. URL: http://www.aimme.es/archivosbd/observatorio_oportunidades/ nano-roadmap_automotive-industry.pdf

5. Серегина С. Ф., Барышев И. А. Закономернолипоявление форсайта? // Форсайт. 2008. № 2(6). T. 2 № 2. C. 4-12.

6. Phaal R., Muller G. (2009) AnArchitecturalFrameworkforRoadmapping: TowardVisualStrategy // TechnologicalForcecastingandSocialChange. № 76. P. 39-49.

7. Н. Талеб. Чорний лебідь: Про (не)ймовірне в реальному житті. Київ : Наш Формат, 2017. 392 c.

8. Лисенко С. О. Майбутній погляд на організацію безпеки: форсайт безпеки і як ним користуватися. Наше право, 2020. № 3. с. 78-84.

9. Clayton A. (2009) Postroeniedorozhnykhkartdlyarazvivayushchikhsyastran [RoadmappinginDevelopingCountries]. Foresight-Russia, vol. 3, no 1, pp. 48-57 (inRussian).

10. Clayton, A. TechnologyRoadmappingforDevelopingCountries. Vienna, UNIDO Publ., 2005.

\section{References:}

1. Mistsevi vybory 2020 i COVID: shcho varto znaty pro pravyla bezpeky [Local elections 2020 and COVID: what you need to know about security rules]. (2020). decentralization.gov.ua. Retrieved from https://decentralization.gov.ua/news/12858?page=3 [in Ukrainian].

2. Zakon Ukrainy "Vyborchyi Kodeks Ukrainy" : vid 19 hrudnia 2019, № 396-IX [Law of Ukraine "Electoral Code of Ukraine" from December 19 2019, № 396-IX]. zakon.rada.gov.ua. Retrieved from https://zakon.rada.gov.ua/laws/show/396-20\#Text [in Ukrainian].

3. Zakon Ukrainy Pro vnesennia zmin do deiakykh zakonodavchykh aktiv Ukrainy shchodo vdoskonalennia vyborchoho zakonodavstva : vid 16 lypnia 2020, № 805-IX [Law of Ukraine On Amendments to Certain Legislative Acts of Ukraine Concerning the Improvement of Electoral Legislation : from July 16 2020, № 805-IX]. zakon.rada.gov.ua. Retrieved from https://zakon.rada.gov.ua/laws/show/805-20\#Text [in Ukrainian].

4. Roadmap Report Concerning the Use of Nanomaterials in the Automotive Sector. Nanomaterial Roadmap 2015. (2006). www.aimme.es. Retrieved from http://www.aimme.es/archivosbd/observatorio_oportunidades/nano-roadmap_automotive-industry.pdf [in English].

5. Seregina, S. F., Baryshev, I. A. (2008). Zakonomernolipoyavlenie forsayta? [Is the 
appearance of a foresight logical?]. Forsayt-Foresight-Russia, 2(2), 4-12 [in Russian].

6. Phaal, R., Muller, G. (2009). An Architectural Framework for Roadmapping: Toward Visual Strategy. Technological Forsecasting and Social Change, 76, 39-49 [in English].

7. Taleb, N. (2017). Chornyi lebid: Pro (ne)ymovirne v realnomu zhytti [Black Swan: About the (un)probable in real life]. Kyiv : Nash Format [in Ukrainian].

8. Lysenko, S. O. (2020). Maibutnii pohliad na orhanizatsiiu bezpeky: forsait bezpeky i yak nym korystuvatysia [Future view on the organization of security: security foresight and how to use it]. Nashe pravo - Our law, 3, 78-84 [in Ukrainian].

9. Clayton, A. (2009). Postroenie dorozhnykh kart dlya razvivayushchikhsya stran [Roadmapping in Developing Countries]. Forsayt-Foresight-Russia, 3(1), 48-57 [in Russian].

10. Clayton, A. (2005). Technology Roadmapping for Developing Countries. Vienna, UNIDO Publ. [in English]. 